\title{
Detection of Enterococcus faecalis in Necrotic Teeth Root Canals by Culture and Polymerase Chain Reaction Methods
}

\author{
Dilsah COGULUa, DDS, PhD \\ Atac UZEL ${ }^{b}$, PhD \\ Ozant ONCAGa, DDS, PhD \\ Semiha C. AKSOYb, PhD \\ Cemal ERONAT', DDS, PhD
}

Objectives: The aim of this study was to investigate the presence of Enterococcus faecalis in endodontic infections in both deciduous and permanent teeth by culture and polymerase chain reaction (PCR) methods.

Methods: A total of 145 children aged 5-13 years old were involved in this study. The presence of $E$. faecalis in necrotic deciduous and permanent teeth root canals was studied using culture and polymerase chain reaction methods.

Results: Among 145 molar teeth, 57\% (n=83) presented necrotic asymptomatic pulp tissues and were included in this study. Culture and PCR methods detected the test species in 18 and 22 of 83 teeth involved, respectively. E. faecalis was cultured from $8(18 \%)$ of 45 necrotic deciduous teeth and from $10(26 \%)$ of 38 necrotic permanent teeth. PCR detection identified the target species in 10 $(22 \%)$ and $12(32 \%)$ of necrotic deciduous and permanent teeth respectively. Statistically significant difference in the presence of $E$. faecalis in deciduous and permanent teeth was found by culture and PCR methods ( $\mathrm{P}=0.03$ and 0.02 , respectively). The difference in the presence of $E$. faecalis between two different methods was not statistically significant $(P>.05)$.

Conclusions: The results of the present study confirm that both culture and PCR methods are sensitive to detect E. faecalis in root canals. (Eur J Dent 2007;1:216-221)

Key words: Enterococcus faecalis; Necrotic tooth; Culture; Polymerase chain reaction.

\section{INTRODUCTION}

Enterococci are common inhabitants of the human gastrointestinal and genitor urinary tracts. ${ }^{1}$

a Ege University, School of Dentistry, Department of Pedodontics, Bornova-Izmir,TURKEY

b Ege University, School of Science,

Department of Biology, Bornova-Izmir, TURKEY

- Corresponding Author: Dilsah COGULU, Ege University, School of Dentistry, Department of Pedodontics 35100 Bornova-Izmir, TURKEY Phone: +90-232-3886431 Fax: +90-232-3880325 e-mail: dilsah.coguluadege.edu.tr
They are also able to colonize a variety of other sites, including the oral cavity. ${ }^{2}$ Enterococci have also been implicated in endodontic infections. Among the enterococci species isolated from root canals, Enterococcus faecalis is the most common species. It is a non-fastidious, therapy-resistant microorganism in infected root canals. ${ }^{3}$ However; it constitutes a small percentage of the microbial species isolated from root canals of teeth with necrotic dental pulp. ${ }^{4}$

Culture methods have provided a great contribution to, and have still much to offer in 
the elucidation of endodontic diseases. However, molecular approaches to detect and identify microbial species have several advantages when compared with culture. Molecular methods, particularly polymerase chain reaction (PCR), are more specific, accurate, sensitive and rapid than culture, and can detect uncultivable and fastidious microorganisms. 5,6 PCR is a technique, which uses a DNA polymerase enzyme to make a huge number of copies of virtually any given piece of DNA or gene. ${ }^{7}$

Although, culture and molecular techniques have been widely used to detect bacteria in endodontic infections, ${ }^{8-10}$ few studies have used them to investigate the microbiota of deciduous teeth. $^{11-13}$

The aim of the present study was to investigate the presence of $E$. faecalis in endodontic infections in both deciduous and permanent teeth by culture and polymerase chain reaction methods.

\section{MATERIALS AND METHODS}

A total of 145 children aged 5-13 years old who attended the Ege University School of Dentistry Department of Pedodontics, Izmir, Turkey with an indication for endodontic treatment were involved in this study. All clinical procedures were approved by the Ethical Committee and informed consent was obtained from each parent. A detailed medical and dental history was obtained from each parent. Patients having received antibiotic therapy in the last 3 months or having a systemic disease were not included. Selected teeth showed no significant gingival recession and were free of periodontal pockets $>4 \mathrm{~mm}$ deep. Teeth which could not be fully isolated with a rubber dam were also not included in the study.

The following clinical features of each patient were recorded: age, gender, tooth and pulp status, clinical signs and symptoms included history of previous pain, spontaneous pain, tenderness to percussion, pain on palpation, mobility, presence of swelling, wet canal, odor and periapical radiolucency. Among 145 children involved in this study, only the ones with necrotic molar teeth were selected. Endodontic samplings were obtained only from these children.

Microbiological sampling

Eigthy-three (45 deciduous, 38 permanent) endodontic samplings from necrotic molar teeth were obtained during the first visit of root canal therapy. After the tooth crown was cleansed with pumice, a rubber-dam was placed. The tooth and the surrounding field were then cleansed with $3 \%$ hydrogen peroxide and decontaminated with a $2.5 \%$ sodium hypochlorite solution for $30 \mathrm{~s}$ each. The solution was inactivated with $5 \%$ sodium thiosulfate. ${ }^{14,15}$ Sampling was performed to check the sterility of the operating field before intracanal sampling procedure in all cases.

Access to the root canal was made using sterile burs without water spray. Aseptic techniques were used for instrumentation, during access to and removal of the contents from the pulp space, and sample collection. In each case, a single root canal was sampled in order to confine the microbial evaluation to a single ecologic environment. The criteria used to choose the canal to be microbiologically investigated in the multirooted teeth was the root canal with periapical radiolucency or the largest canal: in the upper molars palatal canal, in the lower molars distal canal. 9,16 Samples were initially collected by means of \#15 K-type file with the handle cut off. A sterile \#15 file was used to agitate canal contents for $60 \mathrm{~s}^{10}$ The file was introduced to a level approximately $1 \mathrm{~mm}$ short of the tooth apex, based on diagnostic radiographs, and a gentle filing motion was used. Afterwards, two sequential paper points were placed to the same level and used to soak up the fluid in the canal. Each paper point was retained in position for $60 \mathrm{~s}$. If the root canal was dry, a small amount of sterile saline solution was introduced into the canal to ensure viable sample acquisition. Chemical active irrigants were never used before sampling. ${ }^{17}$ The cut file and two paper points were then transferred to sterile $2 \mathrm{ml}$ eppendorf tubes containing VMGA III transport medium. ${ }^{18}$ All samples were processed within 2 hrs. After thoroughly shaking the endodontic sample in a mixer for $60 \mathrm{~s}$ (Vortex, Scientific Industries Inc., Springfield, MA), $1 \mathrm{ml}$ of each sample were used for culture and the other 1 $\mathrm{ml}$ samples were frozen immediately at $-20^{\circ} \mathrm{C}$ and stored until assayed by PCR.

Microbial isolation and identification

The tubes containing samples in VMGA III were preincubated for 30 minutes (min) at $37^{\circ} \mathrm{C}$, 
and shaken vigorously in a vortex mixer (Vortex, Scientific Industries, Inc. Springfield, MAl for 60 s. Serial 10-fold dilutions were made up to 1:106 in $1 \%$ sterile peptone water (Bacto peptone, Difco, Detroit MI, USA). From the serial dilutions, $0.1 \mathrm{ml}$ was transferred and plated on Brucella (BBL, Becton Dickinson Microbiological Systems, Cockeysville, Mdl blood agar plates. The plates were incubated in an anaerobic chamber for 48 $\mathrm{h}$ and the E. faecalis counts were determined as $\mathrm{CFU} / \mathrm{ml}$. The purity of the cultures was confirmed by Gram staining, catalase production, colony morphology on blood agar and using a biochemical identification kit (API 20 Strep, bioMerieux: MarcyI'Etoile, France).

\section{PCR Procedures}

Aliquots of each sample $(1,0 \mathrm{ml})$ were centrifuged at $13,000 \times \mathrm{g}$ for 10 minutes. The resulting pellets were washed with $500 \mu \mathrm{L}$ of phosphate-buffered saline, and placed in $200 \mu \mathrm{L}$ of TE buffer (10mM Tris-Cl pH 7.5, 1 mM EDTA). DNA extraction was performed with "Genomic DNA Purification Kit" (Fermentas GmbH, Germany). Reference DNA from E. faecalis (ATCC 29212) was also extracted to serve as positive control. The DNA concentrations in clinical samples and the concentrations of the reference DNA were determined by spectrophotometric measurement of the absorbance at $260 \mathrm{~nm}$. Serial 10-fold dilutions of known concentration of reference DNA of the target species were processed to determine PCR assay sensitivity. The lowest DNA concentration that resulted in a positive PCR product was regarded as indicative of the sensitivity of the assay. Primer specificity was further tested against reference DNA.

PCR primers, with expected amplicon size and thermocycling parameters used in the present study are shown in Table 1.10,19
The PCR reaction used to assess the occurrence of all target taxa, was performed in $50 \mu \mathrm{l}$ of reaction mixture containing $10 \mu \mathrm{LNA}, 5$ $\mu \mathrm{l}$ 10x PCR buffer, $2 \mathrm{mM} \mathrm{MgCl}, 1.25 \mu \mathrm{l}$ Taq DNA polymerase, $0.2 \mathrm{mM}$ dNTP, $1 \mu \mathrm{M}$ specific primer. Negative controls consisting of ultrapure water instead of sample were included with each batch of samples analyzed. ${ }^{20}$

DNA amplification was performed in a thermal cycler Gene Amp ${ }^{\circledR} \mathrm{PCR}$ system (Applied Biosystems). Amplicons were stored at $-20^{\circ} \mathrm{C}$. The amplification products were analyzed through the use of electrophoresis in a $1.5 \%$ agarose gel conducted at $4 \mathrm{~V} / \mathrm{cm}$ in Tris-borate EDTA buffer. The gels were stained with $0.5 \mu \mathrm{g} / \mathrm{ml}$ ethidium bromide and the PCR products were visualized under $300 \mathrm{~nm}$ ultraviolet light. GeneRuler ${ }^{\circledR}$ DNA Ladder Mix (Fermentas $\mathrm{GmbH}$, Germany).served as the molecular weight marker. The identity of each band was determined by visual comparison with a molecular weight ladder. Reactions were deemed positive in the presence of bands of the appropriate size (Figure 1).

\section{Statistical analysis}

All data were analyzed by using SPSS (SPSS Inc., Chicago, IL, USA) 12.0 software program for windows. Chi-square test was used to compare

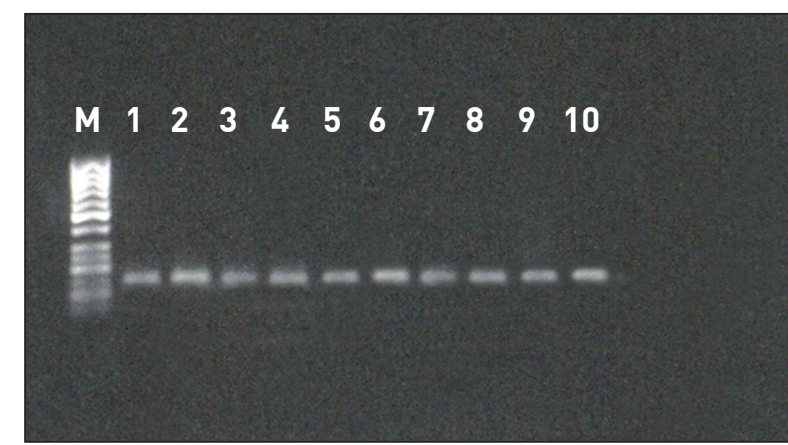

Figure 1. Detection of E. faecalis by PCR.

M: Marker DNA (GeneRuler ${ }^{\circledR}$ DNA Ladder Mix (Fermantas)) 1-10: E.faecalis positive samples

Table 1. PCR primers, with expected amplicon size and thermocycling parameters used in the present study.

\begin{tabular}{|c|c|c|c|}
\hline Target & Sequence ( $5^{\prime}$ to $\left.3^{\prime}\right)$ & Size (bp) & Amplification cycles \\
\hline Universal 16S rDNA & $\begin{array}{l}\text { AGA GTT TGA TCC TGG CTC AG } \\
\text { ACG GCT ACC TTG TTA CGA CTT }\end{array}$ & 1505 & $\begin{array}{c}30 \text { cycles: } \\
94^{\circ} \mathrm{C} 15 \mathrm{~s}, 54^{\circ} \mathrm{C} 15 \mathrm{~s}, \\
72^{\circ} \mathrm{C} 45 \mathrm{~s}\end{array}$ \\
\hline Enterococcus faecalis & $\begin{array}{c}\text { GTT TAT GCC GCA TGG CAT AAG AG } \\
\text { CCG TCA GGG GAC GTT CAG }\end{array}$ & 310 & $\begin{array}{c}36 \text { cycles: } \\
95^{\circ} \mathrm{C} 30 \mathrm{~s}, 60^{\circ} \mathrm{C} 1 \mathrm{~min} \\
72^{\circ} \mathrm{C} 1 \mathrm{~min}\end{array}$ \\
\hline
\end{tabular}


the data.

\section{RESULTS}

Among 145 children, only 83 (57\%) of them had necrotic asymptomatic molar teeth. The presence of $E$. faecalis was evaluated both by culture and PCR methods in these 83 children.

The mean \pm SD age of the children in deciduous tooth group was $7.56 \pm 1.90$ years old, while the mean \pm SD age of the children in permanent tooth group was $10.23 \pm 2.10$ years old.

The difference in the presence of $E$. faecalis in the root canals between the deciduous (18\%) and permanent $(26 \%)$ tooth groups by culture and PCR methods was statistically significant $(P=.03$ and .02, respectively). PCR method was found more sensitive than culture method in both deciduous and permanent teeth. However, the difference between culture and PCR methods in both deciduous and permanent tooth groups was not statistically significant (P>.05)(Table 2).

\section{DISCUSSION}

The presence of $E$. faecalis in the root canals was detected by culture and PCR methods in the present study. E. faecalis was tested because it was reported as therapy-resistant bacteria in the root canals. The success of endodontic treatment depends on several factors, the most important of which is the reduction or elimination of bacterial infection. ${ }^{11}$ Therefore, it is important for the clinician to define this bacteria and its growth ability in the endodontic microenvironment.

Culture and molecular methods are used to detect bacterial species in root canal infections. Bacterial culture identifies the predominant species and has played a key role in the association of specific bacteria of endodontic infections. 9,16,21 Molecular techniques, particularly polymerase chain reaction have been used to detect bacteria in endodontic infections. Molecular techniques can detect uncultivable or difficult-to-grow bacteria. Although culture and molecular techniques have been widely used to detect bacteria in endodontic infections, 8,9 few studies have used to investigate the microbiota in deciduous teeth. ${ }^{11-13}$

Earlier studies using culture methods have reported that E. faecalis is not normally present or is present in very low numbers in the untreated canals. ${ }^{22,23}$ Rocas et al ${ }^{24}$ and Fouad et al ${ }^{25}$ reported a smaller occurrence $(18 \%$ and $8 \%$, respectively) of E. faecalis using molecular techniques. It was also found similar in the present study both by culture and PCR methods. The presence of E. faecalis was also similar in deciduous and permanent teeth groups in the present study.

In the previous reports, the difference between culture and PCR methods was statistically significant. PCR techniquewas found moresensitive than culture method. ${ }^{16,26-28}$ The PCR method was also found more sensitive than culture method in the present study. However, the difference was not statistically significant. There may be two explanations for this result. First; most of the previous reports were performed in secondary infection. The failure of the culture method in those studies should be because of the difficulty during sampling procedure in obturated teeth. In the present study, the sampling procedure was performed in primary infection in both deciduous and permanent teeth. Therefore it can be thought that adequate sample was obtained from each canal for both culture and PCR methods. This was contributed to the similar results with culture and PCR methods. Second; culture methods have some limitations in the detection of especially obligate anaerobic bacteria. Since E. faecalis is facultative anaerobic bacteria, both culture and PCR methods showed similar results.

The presence of E. faecalis in the root canals of the deciduous teeth of young individuals will add knowledge about the presence of this microorganism in the oral cavity since early stages. This is important for the treatment plan for the clinician. The results of the present study confirm that both culture and PCR methods are sensitive to detect $E$. faecalis in both deciduous and permanent teeth. It should be emphasized

Table 2. Detection of E. faecalis by culture and PCR methods.

\begin{tabular}{lccc}
\hline & Presence of $E$. faecalis by culture N (\%) & Presence of E. faecalis by PCR N (\%) \\
\hline Deciduous teeth $\mathrm{n}=45$ & $8(18)$ & $10(22)$ \\
\hline Permanent teeth $\mathrm{n}=38$ & $10(26)$ & $12(32)$ \\
\hline
\end{tabular}


that the PCR technique only detected the target species, but did not enumerate the total number of bacteria present in the samples. This points out the importance of the culture method additionally molecular methods.

\section{CONCLUSIONS}

The results of the present study confirm that both culture and PCR methods are sensitive to detect $E$. faecalis in root canals.

\section{REFERENCES}

1. Murray BE. The life and times of the Enterococcus. Clin Microbiol Rev 1990;3:46-65.

2. Smyth CJ, Matthews $H$, Halpenny MK, Brandis $H$, Colman G. Biotyping, serotyping and band phage typing of Streptococcus faecalis isolated from dental plaque in the human mouth. J Med Microbiol 1987;23:45-84.

3. Molander A, Reit C, Dahlen G, Kvist T. Microbiological status of root-filled teeth with apical periodontitis. Int Endod J 1998;31:1-7.

4. Sundqvist G. Ecology of the root canal flora. J Endod 1992; 18:427-430.

5. Sakamoto M, Takeuchi Y, Umeda M, Ishikawa I, Benno Y. Rapid detection and quantification of five periodontopathic bacteria by real-time PCR. Microbiol Immunol 2001;45:3944.

6. Siqueira JF, Rocas IN. PCR methodology as a valuable tool for identification of endodontic pathogens. J Dent 2003;31:333-339.

7. Spratt DA. Significance of bacterial identification by molecular biology methods. Endod Top 2004;9:5-14.

8. Gomes BP, Pinheiro ET, Sousa EL, Jacinto RC, Zaia AA, Ferraz CC, de Souza-Filho FJ. Enterococcus faecalis in dental root canals detected by culture and by polymerase chain reaction analysis. Oral Surg Oral Med Oral Pathol Oral Radiol Endod 2006;102:247-253.

9. Gomes BP, Jacinto RC, Pinheiro ET, Sousa EL, Zaia AA, Ferraz CC, Souza-Filho FJ. Porphyromonas gingivalis, Porphyromonas endodontalis, Prevotella intermedia and Prevotella nigrescens in endodontic lesions detected by culture and by PCR. Oral Microbiol Immunol 2005;20:211215.

10. Fouad AF, Barry J, Caimano M, Clawson M, Zhu Q, Carver R, Hazlett K, Radolf JD. PCR-based identification of bacteria associated with endodontic infections. J Clin Microbiol 2002;40:3223-3231.

11. da Silva LA, Nelson-Filho P, Faria G, Souza-Gugelmin MC, Ito IY. Bacterial profile in primary teeth with necrotic pulp and periapical lesions. Braz Dent J 2006;17:144-148.
12. Pazelli LC, Freitas AC, Ito IY, Souza-Gugelmin MC, Medeiros AS, Nelson-Filho P. Prevalence of microorganisms in root canals of human deciduous teeth with necrotic pulp and chronic periapical lesions. Pesqui Odontol Bras 2003;17:367371.

13. Ruviere DB, Leonardo MR, Silva LAB, Ito IY, Nelson-Filho $P$. Assessment of the microbiota in root canals of human primary teeth by checkerboard DNA-DNA hybridization. $J$ Dent Child 2007;74:118-123.

14. Siqueira JF Jr, Rocas IN, Rosado AS. Investigation of bacterial communities associated with asymptomatic and symptomatic endodontic infections by denaturating gradient gel electrophoresis fingerprinting approach. Oral Microbiol Immunol 2004;19:363-370.

15. Ng YL, Spratt D, Sriskantharajah S, Gulabivala K. Evaluation of protocols for field decontamination before bacterial sampling of root canals for contemporary microbiology techniques. J Endod 2003;29:317-320.

16. Gomes BP, Pinheiro ET, Gade-Neto CR, Sousa EL, Ferraz CC, Zaia AA, Teixeira FB, Souza-Filho FJ. Microbiological examination of infected dental root canals. Oral Microbiol Immunol 2004;19:71-76.

17. Siqueira JF Jr, Rocas IN, Rosado AS. Investigation of bacterial communities associated with asymptomatic and symptomatic endodontic infections by denaturating gradient gel electrophoresis fingerprinting approach. Oral Microbiol Immunol 2004;19:363-370.

18. Dahlen G, Pipattanagovit P, Rosling B, Moller AJ. A comparison of two transport media for saliva and subgingival samples. Oral Microbiol Immunol 1993;8:375382.

19. Kan VL. Polymerase chain reaction for the diagnosis of candidemia. J Infect Dis 1993;168:779-783.

20. Siqueira JF Jr, Rocas IN. Polymerase chain reactionbased analysis of microorganisms associated with failed endodontic treatment. Oral Surg Oral Med Oral Pathol Oral Radiol Endod 2004;97:85-94.

21. Gomes BP, Drucker DB, Lilley JD. Associations of specific bacteria with some endodontic signs and symptoms. Int Endod J 1994;27:291-298.

22. Sundqvist G. Ecology of the root canal flora. $J$ Endod 1992;18:427-430.

23. Sundqvist G, Fidgor D, Persson S, Sjögren U. Microbiologic analysis of teeth with failed endodontic treatment and the outcome of conservative re-treatment. Oral Surg Oral Med Oral Pathol Oral Radiol Endod 1998;85:86-93.

24. Rocas IN, Siqueira JF Jr, Santos KR. Association of Enterococcus faecalis with different forms of periradicular diseases. J Endod 2004;30:315-320.

25. Fouad AF, Zerella J, Barry J, Spangberg LS. Molecular 
detection of Enterococcus species in root canals of therapy-resistant endodontic infections. Oral Surg Oral Med Oral Pathol Oral Radiol Endod 2005; 99:112-118.

26. Jacinto RC, Gomes BP, Ferraz CC, Zaia AA, Filho FJ. Microbiological analysis of infected root canals from symptomatic and asymptomatic teeth with periapical periodontitis and the antimicrobial susceptibility of some isolated anaerobic bacteria. Oral Microbiol Immunol 2003;18:285-292.

27. Pinheiro ET, Gomes BP, Ferraz CC, Sousa EL, Teixeira FB, Souza-Filho FJ. Microorganisms from canals of root-filled teeth with periapical lesions. Int Endod J 2003;36:1-11.

28. Sundqvist $G$, Johansson E, Sjogren U. Prevalence of blackpigmented bacteroides species in root canal infections. $J$ Endod 1989;15:13-19. 